\title{
Effectiveness of Multimodal Interventions Play Therapy: Colouring and Origami Against Anxiety Levels in Toddler Ages
}

\author{
Helmi Juwita ${ }^{1}$, Fitriani ${ }^{1}$, Akifa Syahrir ${ }^{1}$, Muhammad Taslim², Nur Hidayah ${ }^{3}$,Arbianingsih ${ }^{3}$, Syamsiah \\ Rauf ${ }^{3}$ \\ ${ }^{1}$ Nursing Department, Medical and Health Sciences Faculty, Alauddin State Islamic University of Makassar, \\ Indonesia \\ ${ }^{2}$ College of Health Sciences Panakkukang, Makassar, Indonesia \\ ${ }^{3}$ Lecturer at Department of Nursing Management, Faculty of Medical and Health Sciences, Alauddin State \\ Islamic University, Makassar, Indonesia \\ Correspondence e-mail: helmi.juwita@yahoo.com
}

DOI: http://doi.org/10.29080/jhsp.v3i1.288

\begin{tabular}{l}
\hline Keywords \\
\hline Anxiety \\
Toddler \\
Play \\
Therapy
\end{tabular}

\begin{abstract}
Anxiety is the most common feeling experienced by pediatric patients, especially toddler age (1-3 years) who are hospitalized. Anxiety behavior in toddler age children during hospitalization consists of crying, shouting, refusing to take action, expressing fear, unwillingness to be approached, not wanting to be left behind by parents and unwilling to be approached by nurses or health workers. One effort that can be done to reduce anxiety is through play therapy: colouring and origami activities. The aim of the study was to determine the effectiveness of multimodal interventions play therapy: colouring and origami on anxiety levels in toddler age children. This research is a type of experimental research with a pretest-posttest one group design. Purposive sampling technique was used to recruit 20 children which comprised 10 children in control group and 10 children treatment group. The research instrument used an observation sheet which was modified by Kurniawati.The data was analyzed using paired test and independent test. The study shows there are significant differences in the level of anxiety scores between the intervention group and the control group, where level of anxiety in intervention group is lower than control group. Therefore, the study indicates that multimodal interventions play therapy: colouring and origami are effective against anxiety levels in toddler age children.
\end{abstract}

\section{Introduction}

Illness and hospitalization are the main crises for the toddler. Hospitalization in children can cause anxiety and stress. The prevalence of anxiety disorders that occur in children when in hospital ranges from $60-80 \%$ of the general population. The female group is more than the prevalence of the male group (1).

Anxiety is the most common feeling experienced by pediatric patients, especially toddler age (1-3 years) who are hospitalized. Anxiety behavior in toddler age children during hospitalization are: the crying, shouting, refusing to take action, expressing fear, unwillingness to be approached, reject to be left behind by parents and unwilling to be approached by nurses or health workers (2).

The data from Ar-Rahim room at Haji Hospital in South Sulawesi Province in April-May 2013, there were 114 pediatric patients in the Ar-Rahim room (3). In 2014, the number of pediatric patients in ArRahim room of Haji Hospital was 1,816 children, of whom 790 were children aged 1-4 years (4).

In January 2015, there were 16 patients of toddler age who were treated in the Ar-Rahim room. Based on an interview with one of the nurses in the Ar-Rahim room of Makassar Haji Hospital on 13 July 2015, children who entered the hospital experienced anxiety, as did their parents. One effort that can be done to reduce anxiety is through playing activities. Playing is one of the natural communication tools for children. The need to play still exists even though the child is sick (5). Children can divert their pain (distraction) and relaxation when playing. When the body is relaxed, it will release the endorphin hormone which is soothing, giving effect to emotional stimuli in the limbic system, giving rise to feelings of pleasure. 
Relaxation effects are also expected to reduce physiological responses to anxiety such as a decrease in the pulse.

The choice of game type must be adjusted to the age of children. The type of game which is suitable for toddler is coloring and origami. Coloring has benefits for fun while training the motor nerves, creativity, and imagination of children, as well as providing a stimulus for child development (5). Where as origami can help children understand relatively more complete measures by using more effective strategies for comparison of sizes (6). Therefore, researchers are interested in examining the effectiveness of multimodal play therapy interventions: coloring and origami on anxiety levels in toddler.

\section{Method}

This research was a quasi-experimental design using a pretest-posttestone group design. Respondents in this study were toddlers (1-3 years old). The sampling method used purposive sampling technique with a number of 20 samples, namely 10 control groups and 10 intervention groups. The collected data was then processed and analyzed using paired t test and independent test.

The instrument of data collection used in this study was observation sheets modified by Kurniawati (2008) with assessment techniques for pre-intervention and post-intervention anxiety responses. Play therapy was measured using an observation sheet consisting of 6 items that illustrated the anxiety characteristics of toddler due to hospitalization which is crying, looking sad, usually refusing and not cooperative, denial or denying, shown not to be accompanied and silent her mother.

The observation sheet used has been tested for validity and reliability using validity analysis with product moment formula obtained by the results of $r$ table with $\mathrm{N}=15$ of 0.54 . The basis of decision making in the reliability test is if $r$ alpha is positive from $r$ alpha> $r$ table then the item or variable is reliable. Based on the results of the reliability test for the pretest with alpha formula obtained $r 11$ of 0.728 while the post test was 0.740 . Thus, the overall reliability of the pretest and post test is greater than 0.541 , so the instrument is reliable.

\section{Results}

Table 1

Distribution of Respondents by Age and Gender

\begin{tabular}{cccc}
\hline Criteria & Frequency & $\begin{array}{c}\text { Percentage } \\
\text { (\%) }\end{array}$ \\
\hline Age & $12-23$ & 4 & 20 \\
(month) & $23-36$ & 16 & 80 \\
Total & & $\mathbf{2 0}$ & $\mathbf{1 0 0}$ \\
Gender & Male & 12 & 60 \\
& Female & 8 & 40 \\
Total & & $\mathbf{2 0}$ & $\mathbf{1 0 0}$ \\
\hline Cre: Primary Data, 2015 & &
\end{tabular}

The table above shows that the most respondents were those aged 23-36 months which were 16 people (80\%), while the least were those aged $12-23$ months which were 4 people (20\%). Whereas based on gender, respondents who were male were 12 people $(60 \%)$, while female respondents were 8 people (40\%). 
Table 2

Respondent Anxiety Distribution Pre-Test dan Post-Test

\begin{tabular}{|c|c|c|c|c|c|c|c|c|}
\hline \multirow{3}{*}{ Anxiety } & \multicolumn{4}{|c|}{ Pre-Test } & \multicolumn{4}{|c|}{ Post-Test } \\
\hline & \multicolumn{2}{|c|}{ Control group } & \multicolumn{2}{|c|}{$\begin{array}{c}\text { Intervention } \\
\text { group }\end{array}$} & \multicolumn{2}{|c|}{ Control group } & \multicolumn{2}{|c|}{$\begin{array}{c}\text { Intervention } \\
\text { group }\end{array}$} \\
\hline & $\begin{array}{c}\text { Frequ } \\
\text { ency }\end{array}$ & $\begin{array}{l}\text { Percent } \\
\text { age }(\%)\end{array}$ & $\begin{array}{l}\text { Frequ } \\
\text { ency }\end{array}$ & $\begin{array}{c}\text { Pperce } \\
\text { ntage } \\
(\%)\end{array}$ & $\begin{array}{l}\text { Frequ } \\
\text { ency }\end{array}$ & $\begin{array}{c}\text { Perce } \\
\text { ntage } \\
(\%)\end{array}$ & $\begin{array}{l}\text { Freque } \\
\text { ncy }\end{array}$ & $\begin{array}{c}\text { Perce } \\
\text { ntage } \\
(\%)\end{array}$ \\
\hline Mild & 0 & 0 & 0 & 0 & 0 & 0 & 8 & 80 \\
\hline Moderate & 6 & 60 & 5 & 50 & 6 & 60 & 2 & 20 \\
\hline Severe & 4 & 40 & 5 & 50 & 4 & 40 & 0 & 0 \\
\hline Total & 10 & 100 & 10 & 100 & 10 & 100 & 10 & 100 \\
\hline
\end{tabular}

Source: Primary Data, 2015

The table shows that during the pre-test, the number of respondents who experienced moderate anxiety in the control group was 6 people $(60 \%)$, while in the intervention group there were 5 people (50\%). The number of respondents who experienced severe anxiety in the control group were 4 people (40\%), while in the intervention group there were 5 people (50\%). As for in the post-test, the number of respondents who experienced mild anxiety in the intervention group were 8 people (80\%) and no respondents experienced mild anxiety in the control group. The number of respondents who experienced moderate anxiety in the control group were 6 people $(60 \%)$, while in the intervention group there were 2 people (20\%). The number of respondents who experienced severe anxiety in the control group were 4 people (40\%), while in the intervention group no respondents experienced severe anxiety.

In determining the normality of data distribution, both pretest and posttest data, the Kolmogorov-Smirnov normality test was used (7). The assessment criteria are if the value of $p>0.05$, then the data is normally distributed, on the contrary, if the value was $p<0.05$, then the data is not normally distributed. The results of the normality test data show that the $p$ value in the control group pretest was 0.186 and posttest was 0.436 . While the $p$-value in the intervention group pretest was 0.307 and posttest was 0.201 . This means that the value of $p>0.05$, so it can be concluded that the data distribution is normal variable. Because data is normally distributed, the analysis used was the analysis of paired $t$ tests and independent $t$ test.

In determining changes in anxiety level scores in toddlers in the control group and the intervention group, paired $T$ tests and independent $T$ tests were conducted.

Table 3

Analysis of Anxiety Levels Pretest and Posttest

Multimodal Intervention Therapy Play: Coloring and Origami

\begin{tabular}{cccccc}
\hline \multirow{2}{*}{ Group } & \multicolumn{4}{c}{ Anxiety score } \\
\cline { 2 - 6 } & $\mathbf{n}$ & Mean & $\boldsymbol{p}^{*}$ & Mean & $\boldsymbol{p}^{*}$ \\
Control & 10 & 16,30 & 0,885 & 16,30 & 0,001 \\
* Intervention & 10 & 17,70 & & 08,30 & \\
\hline P value with paired T test (Paired T test)
\end{tabular}

The table shows that pretest multimodal intervention therapy play coloring and origami in the control group has a mean value of 16.30 and the intervention group has a mean value of 17.70. The Sample $T$ Test showed a significant value of $0.885(\mathrm{p}>0.05)$, meaning that there were no differences in anxiety scores before being given multimodal intervention in play therapy: coloring and origami between the control and intervention groups. While posttest multimodal intervention therapy play coloring and origami shows that the control group has a mean value of 16.30 and the intervention group has a mean value of 8.30. The Sample T Test showed a significance value of $0.001(\mathrm{p}<0.05)$, which means there were differences in anxiety scores before being given multimodal play therapy interventions: coloring and origami between the control and intervention groups.

Changes in anxiety level scores in the control and intervention groups 
Table 4

Anxiety Level Difference Analysis in the Intervention and Control Groups

\begin{tabular}{llll}
\hline \multirow{2}{*}{ Group } & \multicolumn{3}{c}{ Anxiety score } \\
\cline { 2 - 4 } & $\mathbf{N}$ & Mean & $\mathbf{P}^{*}$ \\
\hline Control & 10 & 9,40 & \multirow{2}{*}{0,001} \\
Intervention & 10 & 0,00 & \\
\hline * Value $p$ with independent $T$ Test
\end{tabular}

The table shows that the intervention group has a mean value of 9.40 and the control group has a mean value of 0.001 . The Independent $T$ test shows a significance value of $0.001(p<0.05)$, which means that there is a significant difference in the level of anxiety scores that are significant between the intervention group and the control group, where the change in score difference in anxiety level is greater in the intervention group.

\section{Discussion}

In this study, it was found that toddlers who had been given multimodal play therapy: coloring and origami still experienced anxiety, but the level of anxiety decreased compared to the anxiety experienced before intervention. This is in line with the research conducted by Indrawaty (2013) and Indriani (2014) which shows that there is a decrease in toddler anxiety after play therapy $(8,9)$.

Play therapy is one way to reduce anxiety and improve child cooperation during intervention at the hospital. This is in line with several studies conducted by Silva et al (2017) and Meiri et al (2016) which show that play therapy can reduce anxiety in children aged 2-10 years. Playing is a safe way to externalize worries, fears, and feelings. Playing is a projective activity in which a child who has not fully acquired cognitive and verbal communication skills can express himself freely. In addition, playing has a catharsis function that directly affects the child's emotional state, releasing tension and emotions that may not be socially acceptable, such as anger and aggression $(10,11)$.

Sigmund Freud based on the Psychoanalytic Theory says that the function of play is to express impulse exclusively as a way to reduce excessive anxiety in children. The form of play activity is shown in the form of playing fantasy and imagination in playing coloring and origami so that children can express hopes and conflicts and experiences that cannot be realized.

This research has proven that playing can reduce anxiety in children in hospitals. This study also answers the Theory of Caring from Kristen M Swanson that in providing nursing services trying to find the physical and psychological needs of clients and in this case are toddler-age children who are getting care with the application of caring values. The caring values are in the form of an effort to understand the values believed by the child by paying attention to the feelings they feel, such as separation anxiety, feeling of losing control, fear of injury.

One suitable game for toddlers is coloring pictures. Coloring is one of the educational game tools (APE) because it can develop aspects of a child's development and encourage children's activities and creativity (12). The picture of coloring game is one of the most important aspects of a child's life and is one of the most effective ways to deal with stress. Drawing or coloring is a game that gives children opportunity to freely express feelings and a way to communicate, without using words (13). This is in accordance with the research conducted by Hsu and Feng (2015) who examined coloring in children treated in PICU (14). This strategy is successful in helping children to overcome the pressure felt by hospitalization and working with health care providers in their care. This is also in line with research conducted by Felipo (2011), Clatworthy, Simon, and Tiedeman (2014) who examined coloring in children who were hospitalized (15).

In addition to coloring, a suitable game for toddler-age children is origami. Origami is an art where various shapes can be created by folding paper. Origami can train fine motor skills, foster motivation, creativity, perseverance, and skill (16).

The results of this study are supported by research conducted by Siti Aizah (2014) about the effect of coloring therapy on anxiety levels as the effect of hospitalization on pre-school age children. The results of the study stated that there was an effect of playing coloring on anxiety levels as the effect of hospitalization on children (17).

In the human brain, there is a structure that surrounds the base of the brain, the limbic system that can control emotions and behavior. In the limbic system, there is an amygdala, which serves as the brain's emotional memory bank, where all good memories of glory and failure, hope and fear, aggravation and frustration are stored. Another brain structure is the hippocampus which brings back special information independently that has certain emotional values (18).

Pain and being hospitalized is an unpleasant experience for children. At that time, the data that enters through the five senses (sight, smell, accent, hearing, and touch) all enter through the midbrain (thalamus) and are recorded, unconsciously stored by the hippocampus and the emotional charge 
stored in the amygdala. Through coloring images, a person unconsciously releases an amygdala charge, which expresses sadness, stress, stress, anxiety, and creates images that make children feel happy again so they can create positive coping. Positive coping is characterized by positive behaviors and emotions that will help reduce stress or anxiety experienced by children (19). Besides that, playing coloring and origami is easy to implement and access because it is efficient and is a fun and fast activity to do, and is ready to be accepted by the child.

In general, toddlers aged hospitalizations experience anxiety or stress in hospitalization. One way to reduce anxiety is by playing. The game can be more than one game, namely are coloring and origami to reduce the saturation of children while playing in the hospital.

\section{Conclusion and Suggestion}

Multimodal interventions for play therapy: coloring and origami are effective against anxiety levels in toddlers, from moderate and severe to mild and moderate. Playing with children is one way of learning and to eliminate child boredom. But it is necessary to do a similar study or with other types of games with more respondents in order to get better results using pure experimental methods.

\section{Acknowledgment}

The authors acknowledge the children and their parents for being involved in this study as well as nurses in Ar-Rahim Room of Haji Hospital.

\section{References}

1. Purmailani. Pengaruh Pendekatan Family Centered Care Terhadap Penurunan Kecemasan Anak Usia Toddler di Rumah Sakit Emanuel Klampok Banjarnegara. Universitas Muhammadiyah Purwokerto; 2014.

2. Alang. Kesehatan Mental. Makassar: UIN Alauddin; 2011.

3. Rahmi. Gambaran Peran Keluarga dan Tingkat Kecemasan Anak Usia Sekolah (6-12 Tahun) Akibat Hospitalisasi di RSUD Haji. Makassar: UIN Alauddin; 2013.

4. Medical Records. Medical Records RSUD Haji. RSUD Haji Provinsi Sulawesi Selatan; 2015.

5. Suryanti S dan Y. Pengaruh Terapi Bermain Mewarnai dan Origami Terhadap Tingkat Keceasan Sebagai Efek Hospitalisasi pada Anak Usia Pra Sekolah di RSUD Dr.R.Goetheng Tarunadibrata Purbalingga.. J Kesehat Samodra Ilmu [Internet]. 2012;03 (02). Available from: http://fmipa.umri.ac.id/wp-content/uploads/2016/04/jurnal-edisi-VI.pdf\#page=3

6. Pandiangan. Segudang Manfaat Origami Untuk Anak. 2011;

7. Dahlan. Statistik untuk Kedokteran dan Kesehatan. Jakarta: Salemba Medika; 2011.

8. Indtawaty L. Tingkat Kecemasan Anak Usia Toddler Akibat Hospitalisasi Di Ruang Rawat Inap Anak Rsud Kota Bekasi Tahun 2013 Lina Indrawaty Program Studi S1 Ilmu Keperawatan Sekolah Tinggi Ilmu Keperawatan Medistra Indonesia. 2014;1:7. Available from: https://ayurvedamedistra.files.wordpress.com/.../pengaruh-pemberian-terapi-aktivitas-...

9. Noverita M\& M. Terapi Bermain Terhadap Tingkat Kecemasan Pada Anak Usia 3??5 Tahun Yang Berobat Di Puskesmas Peukan Baro. J Ilmu Keperawatan [Internet]. 2017;5(2):67-78. Available from: file:///C:/Users/HP/Downloads/10539-26005-2-PB (7).pdf 
10. Meiri N, Ankri A, Hamad-Saied M, Konopnicki M, Pillar G. The effect of medical clowning on reducing pain, crying, and anxiety in children aged 2-10 years old undergoing venous blood drawing—a randomized controlled study. Eur J Pediatr. 2016;175(3):373-9.

11. Silva et al. Influence of Therapeutic Play on the anxiety of hospitalized school-age children: Clinical trial. Rev Bras Enferm. 2017;70(6):1244-9.

12. Astini BN, Nurhasanah, Rachmayani I, Suarta IN. Identifikasi Pemanfaatan Alat Permainan Edukatif (APE) Dalam Mengembangkan Motorik Halus Anak Usia Dini. J Pendidik Anak. 2017;6:31-40.

13. Utami Y. Dampak Hospitalisasi Terhadap Perkembangan Anak. J Ilm WIDYA [Internet]. 2014;9(2):9-20. Available from: http://digilib.mercubuana.ac.id/ manager/ t\%21 @ file_a rtikel_ abstrak/Isi_Artikel_891255124583.pdf

14. Hsu CH \& Feng JY. The use of therapeutic play in the intensive care of a preschool child with virusassociated hemophagocytic syndrome. 2015;62(2):96-102. Available from: https://www.ncbi.nlm.nih.gov/pubmed/25854953

15. Felipo M. Child drawings and psychological problems in paediatrics hospitalization (author's transl. 2011;10:652. Available from: https://www.ncbi.nlm.nih.gov/pubmed/727599

16. Paat P. Kreasikotakdengan origami. Yogyakarta: Grasindo; 2013.

17. Aizah S, Wati SE. Upaya Menurunkan Tingkat Stres Hospitalisasi Dengan Aktifitas Mewarnai Gambar pada Anak Usia 4-6 Tahun di Ruang Anggrek RSUD Gambiran Kediri. Ejornal Kedokt Univ Airlangga. 2014;25(1):6-10.

18. Satyanegara. Ilmu Bedah Saraf. Jakarta: Gramedia Pustaka Utama;

19. Hidayat. Pengantar Ilmu Keperawatan Anak 1. Jakarta: Salemba Medika; 2009. 